\title{
MOG antibody-positive, benign, unilateral, cerebral cortical encephalitis with epilepsy
}

\section{OPEN}

Ryo Ogawa, MD

Ichiro Nakashima, MD, $\mathrm{PhD}$

Toshiyuki Takahashi, $\mathrm{MD}, \mathrm{PhD}$

Kimihiko Kaneko, MD

Tetsuya Akaishi, MD

Yoshiki Takai, MD, PhD

Douglas Kazutoshi Sato,

$\mathrm{MD}, \mathrm{PhD}$

Shuhei Nishiyama, MD, $\mathrm{PhD}$

Tatsuro Misu, MD, PhD

Hiroshi Kuroda, MD, $\mathrm{PhD}$

Masashi Aoki, MD, PhD

Kazuo Fujihara, MD,

$\mathrm{PhD}$

Correspondence to

Dr. Nakashima:

nakashima@med.tohoku.ac.jp

\section{ABSTRACT}

Objective: To describe the features of adult patients with benign, unilateral cerebral cortical encephalitis positive for the myelin oligodendrocyte glycoprotein (MOG) antibody.

Methods: In this retrospective, cross-sectional study, after we encountered an index case of MOG antibody-positive unilateral cortical encephalitis with epileptic seizure, we tested for MOG antibody using our in-house, cell-based assay in a cohort of 24 consecutive adult patients with steroid-responsive encephalitis of unknown etiology seen at Tohoku University Hospital (20082014). We then analyzed the findings in MOG antibody-positive cases.

Results: Three more patients, as well as the index case, were MOG antibody-positive, and all were adult men (median age 37 years, range 23-39 years). The main symptom was generalized epileptic seizure with or without abnormal behavior or consciousness disturbance. Two patients also developed unilateral benign optic neuritis (before or after seizure). In all patients, brain MRI demonstrated unilateral cerebral cortical fluid-attenuated inversion recovery hyperintense lesions, which were swollen and corresponded to hyperperfusion on SPECT. CSF studies showed moderate mononuclear pleocytosis with some polymorphonuclear cells and mildly elevated total protein levels, but myelin basic protein was not elevated. A screening of encephalitis-associated autoantibodies, including aquaporin-4, glutamate receptor, and voltage-gated potassium channel antibodies, was negative. All patients received antiepilepsy drugs and fully recovered after highdose methylprednisolone, and the unilateral cortical MRI lesions subsequently disappeared. No patient experienced relapse.

Conclusions: These MOG antibody-positive cases represent unique benign unilateral cortical encephalitis with epileptic seizure. The pathology may be autoimmune, although the findings differ from MOG antibody-associated demyelination and Rasmussen and other known immune-mediated encephalitides. Neurol Neuroimmunol Neuroinflamm 2017;4:e322; doi: 10.1212/NXI.0000000000000322

\section{GLOSSARY}

ADEM = acute disseminated encephalomyelitis; AMPA $=\alpha$-amino-3-hydroxy-5-methyl-4-isoxazole propionic acid receptor; AQP4 = aquaporin-4; CASPR2 = contactin-associated protein 2; $\mathbf{C B A}=$ cell-based assay; $\mathbf{C B C}=$ complete blood count; $\mathbf{C F F}=$ critical flicker frequency; $\mathbf{D W I}=$ diffusion-weighted imaging; $\mathbf{E A E}=$ experimental autoimmune encephalomyelitis; FLAIR = fluid-attenuated inversion recovery; $\mathbf{G A B A B}=\gamma$-aminobutyric acid receptor type $\mathrm{B}$ receptor; $\mathbf{G A D}=$ glutamic acid decarboxylase; GdT1WI = gadolinium enhancement on T1-weighted imaging; HIMP = high-dose IV methylprednisolone; HSV = herpes simplex virus; IgG = immunoglobulin G; IL-6 = interleukin-6; LETM = longitudinally extensive transverse myelitis; LGI1 = leucine-rich glioma-inactivated protein 1; MBP = myelin basic protein; MOG = myelin oligodendrocyte glycoprotein; $\mathbf{M S}=$ multiple sclerosis; NMDAR = NMDA receptor; NMOSD = neuromyelitis optica spectrum disorder; $\mathbf{O N}=$ optic neuritis; $\mathbf{P S L}=$ prednisolone; $\mathbf{R E}=$ Rasmussen encephalitis; $\mathbf{T 2 W I}=$ T2-weighted imaging; $\mathbf{T g}=$ thyroglobulin; TPO $=$ thyroid peroxidase; VA = visual acuity; VEP = visual evoked potential.

Myelin oligodendrocyte glycoprotein (MOG) is a myelin protein expressed at the outermost lamellae of the myelin sheath in the CNS. ${ }^{1-3}$ MOG is also used as an immunogen for experimental autoimmune encephalomyelitis (EAE). ${ }^{2-5} \mathrm{EAE}$ studies have suggested that MOG

From the Department of Neurology (R.O., I.N., T.T., K.K., T.A., Y.T., D.K.S., S.N., T.M., H.K., M.A., K.F.), Tohoku University Graduate School of Medicine, Sendai; Department of Neurology (T.T.), Yonezawa National Hospital, Yamagata, Japan; Brain Institute (D.K.S.), The Pontifical Catholic University of Rio Grande do Sul, Porto Alegre, Brazil; Department of Multiple Sclerosis Therapeutics (K.F.), Fukushima Medical University; and Multiple Sclerosis \& Neuromyelitis Optica Center (K.F.), Southern Tohoku Research Institute for Neuroscience, Koriyama, Japan.

Funding information and disclosures are provided at the end of the article. Go to Neurology.org/nn for full disclosure forms. The Article Processing Charge was paid by the authors.

This is an open access article distributed under the terms of the Creative Commons Attribution-NonCommercial-NoDerivatives License 4.0 (CC BY-NC-ND), which permits downloading and sharing the work provided it is properly cited. The work cannot be changed in any way or used commercially without permission from the journal. 
Table 1 Clinical features of 4 patients with unilateral cortical encephalitis positive for the MOG antibody

\begin{tabular}{|c|c|c|c|c|}
\hline & Patient 1 (index case) & Patient 2 & Patient 3 & Patient 4 \\
\hline Sex/age at onset, y & M/39 & $M / 36$ & M/23 & $\mathrm{M} / 38$ \\
\hline \multicolumn{5}{|l|}{ Clinical manifestations } \\
\hline \multicolumn{5}{|l|}{ Encephalopathy } \\
\hline Epileptic seizure & $\begin{array}{l}\text { Generalized tonic } \\
\text { seizure with Todd } \\
\text { palsy }\end{array}$ & $\begin{array}{l}\text { Generalized tonic } \\
\text { seizure }\end{array}$ & $\begin{array}{l}\text { Involuntary movement of the } \\
\text { left hand, generalized tonic } \\
\text { seizure }\end{array}$ & $\begin{array}{l}\text { Generalized tonic seizure } \\
\text { initially involved the right } \\
\text { hand }\end{array}$ \\
\hline $\begin{array}{l}\text { Disturbance of } \\
\text { consciousness }\end{array}$ & Delirium & Only in seizure & Disorientation & Only in seizure \\
\hline $\begin{array}{l}\text { Abnormal behavior and } \\
\text { psychiatric symptoms }\end{array}$ & $\begin{array}{l}\text { Paranoia, hallucination, } \\
\text { anorexia }\end{array}$ & - & - & Agitation, violent behavior \\
\hline $\begin{array}{l}\text { Other focal brain } \\
\text { symptoms }\end{array}$ & - & - & - & $\begin{array}{l}\text { Aphasia and right } \\
\text { hemiparesis }\end{array}$ \\
\hline Optic neuritis & $\begin{array}{l}+(\mathrm{R}, 7 \text { months } \\
\text { before seizure) }\end{array}$ & $+(R$, after seizure $)$ & - & - \\
\hline Myelitis & - & - & - & - \\
\hline \multicolumn{5}{|l|}{ Brain MRI } \\
\hline FLAIR hyperintensity & R frontoparietal cortex & $\begin{array}{l}\mathrm{R} \text { frontoparietal } \\
\text { cortex }\end{array}$ & R parietal cortex & $L$ hemisphere cortex \\
\hline ADEM-like brain lesion & - & - & - & - \\
\hline \multicolumn{5}{|l|}{ CSF at acute phase } \\
\hline $\begin{array}{l}\text { Cell counts/ } \mu \mathrm{L} \text { (mono: } \\
\text { poly) }\end{array}$ & $29(23: 6)$ & $63(62: 1)$ & $101(51: 50)$ & 311 (129:182) \\
\hline Protein, mg/dL & 35 & 38 & 86 & 53 \\
\hline Oligoclonal IgG bands & No data & - & - & - \\
\hline $\mathrm{MBP}, \mathrm{pg} / \mathrm{mL}$ & No data & $<31.3$ & $<31.3$ & $<31.3$ \\
\hline \multicolumn{5}{|l|}{ MOG antibody titer } \\
\hline Serum (onset) & $1: 512$ & $1: 2,048$ & 1:256 & $1: 1,024$ \\
\hline Serum (remission) & 1:16 & $1: 128$ & - & - \\
\hline CSF & $1: 32$ & $1: 4$ & 1:16 & No sample \\
\hline Treatment & HIMP, PSL, CBZ, LTG & HIMP, PSL, CBZ & DEX, PSL, CBZ & HIMP, PSL, CBZ \\
\hline Response to treatments & $\begin{array}{l}\text { Full recovery after } \\
\text { HIMP }\end{array}$ & $\begin{array}{l}\text { Full recovery after } \\
\text { HIMP }\end{array}$ & Full recovery after DEX & Full recovery after HIMP \\
\hline Relapse & No & No & No & No \\
\hline Duration of follow-up, mo & 30 & 40 & 23 & 72 \\
\hline
\end{tabular}

Abbreviations: $\mathrm{ADEM}=$ acute disseminated encephalomyelitis; $\mathrm{CBZ}$ = carbamazepine; $\mathrm{DEX}=$ dexamethasone; FLAIR = fluid-attenuated inversion recovery; HIMP = high-dose IV methylprednisolone; lgG = immunoglobulin G; LTG = lamotrigine; $\mathrm{MBP}=$ myelin basic protein; MOG = myelin oligodendrocyte glycoprotein; PSL = prednisolone.

antibodies play a direct pathogenetic role in the animal model of inflammatory demyelinating disease, although previous studies designed to detect MOG antibody with the ELISA or Western blotting in human inflammatory demyelinating diseases have failed to reveal any characteristic findings in patients. ${ }^{3,6,7}$ However, recent studies have demonstrated that conformation-sensitive MOG antibody can be detected by cell-based assays (CBAs) in patients without multiple sclerosis (MS), such as those with pediatric acute disseminated encephalomyelitis (ADEM), aquaporin-4 (AQP4)-immunoglobulin $\quad G$ (IgG)-negative neuromyelitis optica spectrum disorders (NMOSD), optic neuritis (ON), and longitudinally extensive transverse myelitis (LETM). ${ }^{2,3,8-12}$ These findings suggest that the MOG antibody may serve as a biomarker to define a spectrum of inflammatory demyelinating diseases, and extensive studies of MOG antibody-positive cases may identify new clinical phenotypes directly or indirectly associated with this myelin antibody.

In the present study, we encountered an index case of MOG antibody-positive 

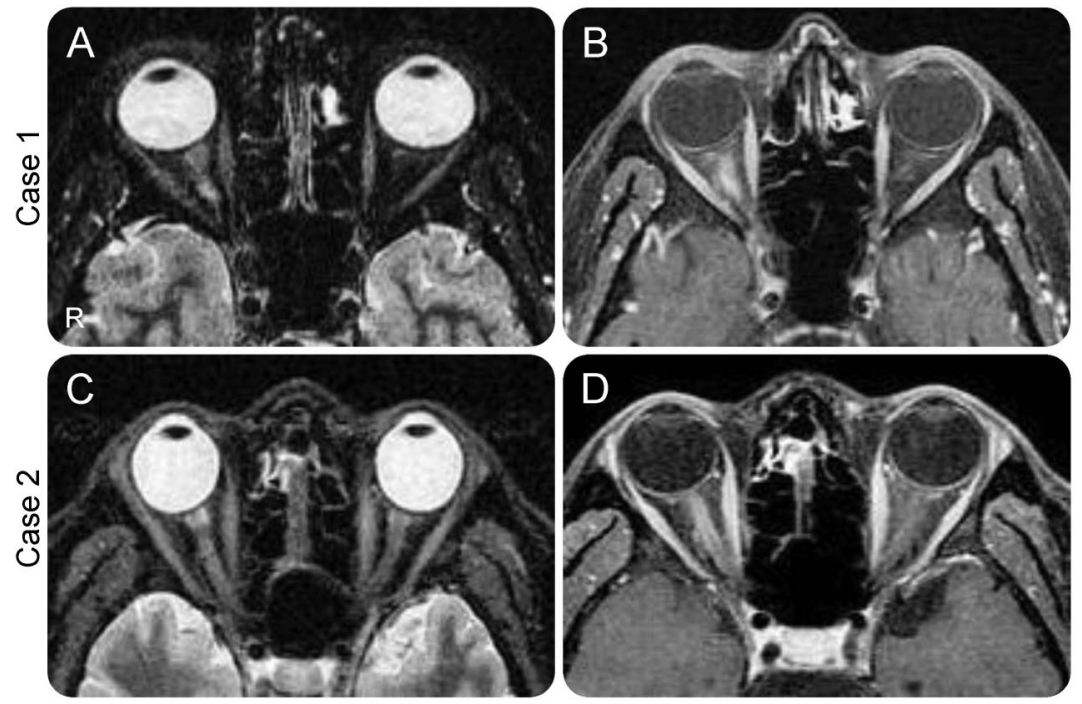

Hyperintensities on axial short T1 inversion recovery $(A, C)$ and gadolinium enhancement $(B$, D) were seen in the right optic nerves in cases 1 (A, B) and 2 (C, D), suggesting unilateral optic neuritis.

benign unilateral cerebral cortical encephalitis manifesting with generalized epileptic seizure and then investigated the presence of MOG antibody in an adult cohort of patients with steroid-responsive encephalitis of unknown etiology to identify any unique features of encephalitis in MOG antibody-positive cases.

Figure 2 Brain MRI findings in case 1
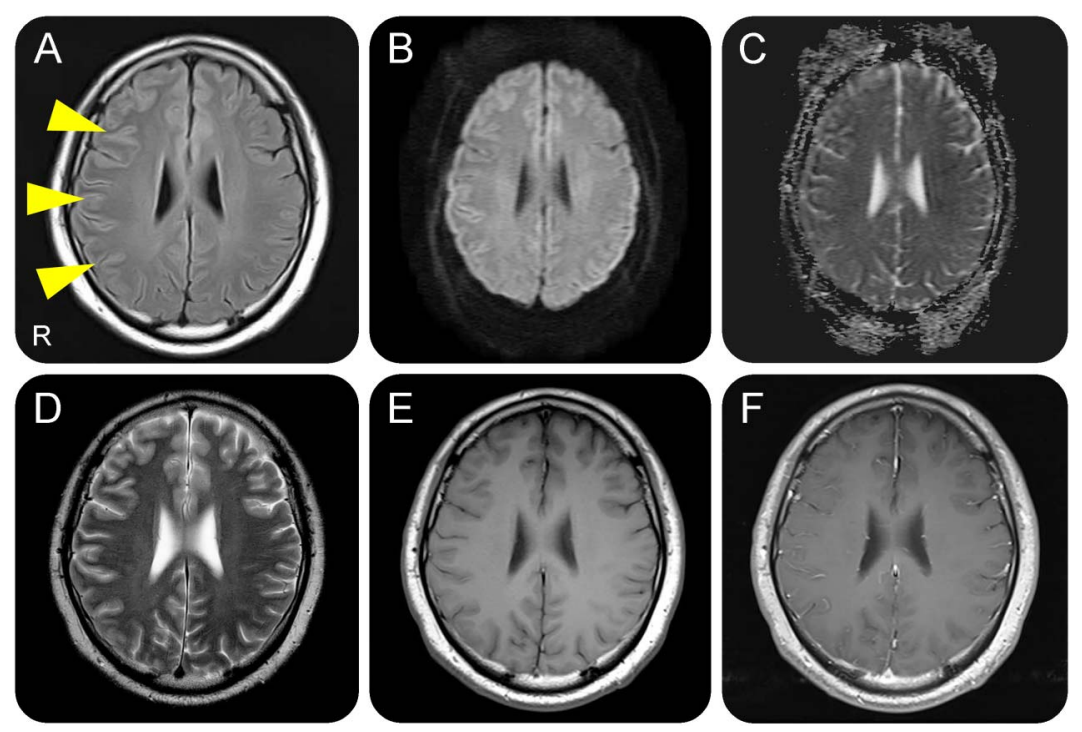

When hospitalized with epileptic seizure, the right hemispheric cortical region in case 1 was fluid-attenuated inversion recovery hyperintense (A) (arrowheads) and partially gadolinium enhanced. Meanwhile, hyperintensities in the cortical region were less evident on diffusion-weighted (B), apparent diffusion coefficient (C), T2-weighted (D), T1-weighted (E), and gadolinium enhancement on T1-weighted (F) MRI.

METHODS Patients, sera, and CSF. We encountered an adult patient (index case, case 1) with unique benign unilateral cerebral cortical encephalitis manifesting with generalized epileptic seizure and seropositivity for MOG antibody in 2014. To explore any other cases with similar features, we identified 24 consecutive patients diagnosed with steroid-responsive encephalitis of unknown etiology seen at Tohoku University Hospital from 2008 to 2014. The patients were older than 20 years and were followed for more than 19 months. We defined steroid-responsive encephalitis of unknown etiology as cases with encephalopathy (epileptic seizure, abnormal behavior, disturbance of consciousness, or focal brain symptoms) that responded to corticosteroid therapy and could not be explained by fever, systemic illnesses, or postictal symptoms. Additional criteria included abnormal brain MRI and CSF findings during the acute phase that were compatible with encephalitis and not indicative of alternative CNS diseases. Sera and CSF were collected during the acute phases and were stored at $-80^{\circ} \mathrm{C}$. In some cases, sera obtained during remission phases were also stored.

Assays for autoantibodies. We conducted live CBA for MOG antibody based on our previous reports with modification (we used anti-human IgG1 as the secondary antibody to avoid nonspecific binding $\left.{ }^{8,10}\right)$. Briefly, full-length MOG-expressing or MOG-nonexpressing stable cell lines were incubated with a 1:16 dilution of serum and then incubated with a 1:400 dilution of Alexa Fluor 488 mouse anti-human IgG1 antibody (A10631; Thermo Fisher Scientific, Rockford, IL). After cell immunostaining, 2 investigators (R.O. and T.T.), who were blinded to patients' data, judged MOG antibody positivity by comparing the staining results of MOG-expressing and MOG-nonexpressing cells. In MOG antibody-positive samples, the antibody titers were calculated by consecutive twofold dilutions to ascertain the maximum dilution with positive staining. Simultaneously, M23-AQP4 antibody in the serum was tested by live CBA using Alexa Fluor 488 goat anti-human IgG (A11008, Thermo Fisher Scientific) as the secondary antibody. Anti-NMDA receptor (NMDAR) antibody, anti- $\alpha$-amino-3-hydroxy-5-methyl-4-isoxazole propionic acid receptor (AMPA) antibody, anti-leucine-rich gliomainactivated protein 1 (LGI1) antibody, anti-contactin-associated protein 2 (CASPR2) antibody, and anti- $\boldsymbol{\gamma}$-aminobutyric acid receptor type $B$ receptor $\left(\mathrm{GABA}_{\mathrm{B}}\right)$ antibody in the CSF were tested by indirect immunofluorescence using commercially available kits (Euroimmun, Lübeck, Germany).

Standard protocol approvals, registrations, and patient consents. This study was approved by the institutional ethics committee, and all patients provided written informed consent.

RESULTS In addition to the index case, 3 other patients were found to be seropositive for MOG antibody. The clinical characteristics of these 4 patients are summarized in table 1 . All of these patients were male, and the median onset age was 34 years (range 23-39). All of the patients experienced epileptic seizures, 3 showed abnormal behavior, 2 patients had ON (figure 1), and 1 patient had dysuria, but no patient had myelopathy. In CSF examinations, the median cell count was $83 / \mu \mathrm{L}$ (range 29-311), and the median protein concentration was $46 \mathrm{mg} / \mathrm{dL}$ (range 35-86). Myelin basic protein (MBP) in CSF was not elevated in any of the 3 patients (cases 1, 2, and 3) whose CSF samples were available, although 
they were positive for MOG antibody in the CSF. On brain MRI examination, all 4 cases showed unilateral hemispheric cortical hyperintense lesions in fluid-attenuated recovery (FLAIR) imaging (figure 2A and figure 3, A-C, F-H, J-R, and T). None of the MOG antibody-negative patients in our cohort of encephalitis patients showed such FLAIR-hyperintense cortical lesions. The $4 \mathrm{MOG}$ antibody-positive patients were treated with high-dose IV corticosteroids and antiepilepsy drugs, and they fully recovered. We also screened for other encephalitis-related autoantibodies, including AQP4, NMDAR, AMPA, LGI1, CASPR2, and $G_{A B A}$ antibodies, but negative results were obtained for all of the cases.

Case presentation. Case 1 (index case). A 38-year-old man developed right eye pain and visual loss. His visual acuity (VA) was 30/200, and the critical flicker frequency (CFF) was $16.4 \mathrm{~Hz}$ (normal >35) in his right eye. He presented with a right relative afferent pupillary defect and color vision defect in the right eye. Fundus examination revealed optic disc swelling in the right eye. Regarding visual evoked potentials (VEP), the amplitude of P100 was reduced with prolonged latency in the right eye (120.6 ms). This patient was diagnosed with idiopathic ON (figure 1, $\mathrm{A}$ and $\mathrm{B})$ and treated with high-dose IV methylprednisolone (HIMP) $(1,000 \mathrm{mg} / \mathrm{d}$ for 3 days) followed by an oral prednisolone (PSL) taper. His visual symptoms greatly improved soon after HIMP. Seven months later, the patient acutely developed loss of consciousness and generalized tonic seizure and was admitted to our hospital. On admission, he was alert, but his left hand was weak due to Todd palsy. Complete blood cell counts (CBC) and biochemistry were normal. A CSF study showed mild pleocytosis and elevated interleukin-6 (IL-6; $72.6 \mathrm{pg} / \mathrm{mL}$, normal $<4.0 \mathrm{pg} / \mathrm{mL}$ ). Glutamic acid decarboxylase (GAD) antibody, thyroid peroxidase (TPO) antibody, and thyroglobulin $(\mathrm{Tg})$ antibody results were negative in the serum, but the MOG antibody test was positive in the serum (1:512) and in the CSF (1:32) (table 1). EEG showed rhythmic slow waves in the right cerebral hemisphere but no epileptic discharge in the interictal stage. Brain MRI scanned on the day of epilepsy onset showed FLAIR hyperintensity in the right hemispheric cortical region, and the cortical layer was mildly swollen (figure 3, A-C) but did
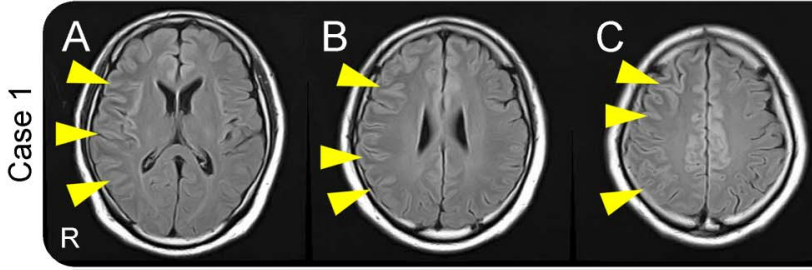

D
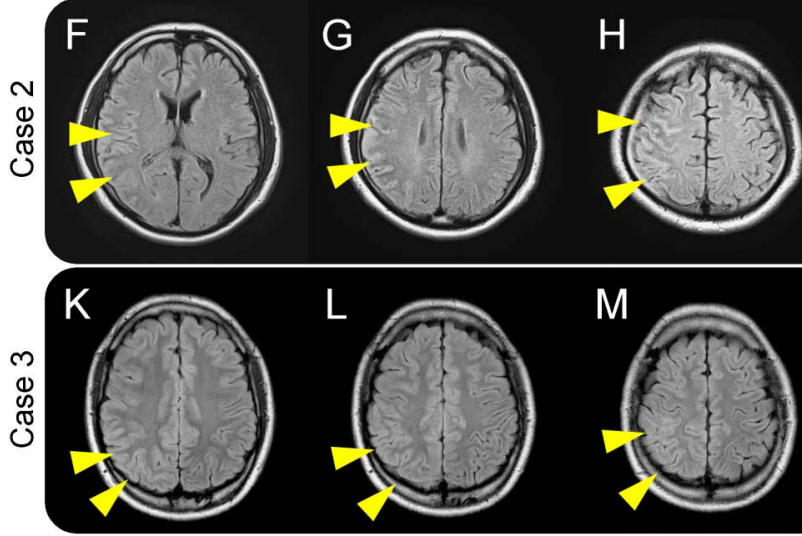

$\mathrm{N}$
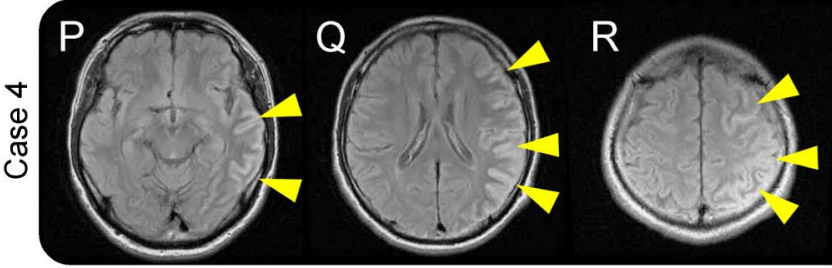
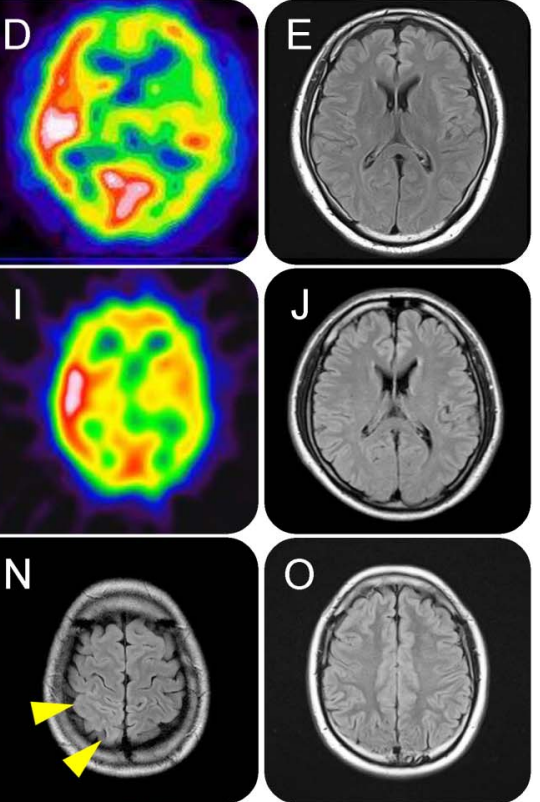

On admission, fluid-attenuated inversion recovery (FLAIR) hyperintensity was seen in the unilateral cerebral cortex in cases $1(\mathrm{~A}-\mathrm{C}), 2(\mathrm{~F}-\mathrm{H}), 3(\mathrm{~K}-\mathrm{N})$, and $4(\mathrm{P}-\mathrm{R})$ (arrowheads). Brain SPECT showed hyperperfusion in those cerebral cortical regions with FLAIR hyperintensity in cases 1 (D), 2 (I), and 4 (S). However, the FLAIR hyperintensities in the cortical regions disappeared after more than 2 years $(E, J, O, T)$. 
not show gadolinium enhancement on T1-weighted imaging (GdT1WI). Slight hyperintensity in the regions of diffusion-weighted imaging (DWI) and T2-weighted imaging (T2WI) were seen but were less evident than in the FLAIR image (figure 2, A-F). Brain SPECT showed hyperperfusion in the region (figure 3D). Whole-body PET-CT scans showed no malignancy or inflammation. We started carbamazepine (400 $\mathrm{mg} / \mathrm{d})$ and lamotrigine $(25 \mathrm{mg} / \mathrm{d})$, but 1 week later, the patient developed delirium, paranoia, hallucination, and anorexia. His symptoms worsened despite risperidone administration. Subsequently, we made a presumptive diagnosis of autoimmune encephalitis to start HIMP therapy, and his symptoms disappeared within a few days. Eight weeks after admission, he was asymptomatic and therefore discharged. He continued oral prednisolone $(15 \mathrm{mg} / \mathrm{d}$, then gradually tapered to $4 \mathrm{mg} / \mathrm{d}$ in 18 months), carbamazepine, and lamotrigine and experienced no relapse thereafter. At 26 months after discharge, his serum MOG antibody titer had decreased substantially (1:16). Brain MRI showed no residual lesions 30 months after discharge (figure $3 \mathrm{E}$ ).

Case 2. A 36-year-old man let out a strange noise and lost consciousness for several minutes, resulting in a one-car accident when he was driving a car. $\mathrm{He}$ was admitted to a local hospital that day and was treated with carbamazepine $(400 \mathrm{mg} / \mathrm{d})$. Brain MRI taken on admission showed a FLAIR-hyperintense area in the right parietal cortex. After admission, he twice developed a generalized tonic seizure, right eye pain with visual loss, and dysuria. He was then transferred to our hospital. Neurologic examination showed impaired right VA and dysuria but no signs of meningeal irritation. His VA was normal, but visual field testing showed central scotoma. The CFF was $25 \mathrm{~Hz}$, and VEP revealed prolonged P100 latency (128.4 ms). CBC and blood biochemistry results were normal, while the MOG antibody test was positive in the serum $(1: 2,048)$ and in the CSF (1:4) (table 1). The GAD antibody, TPO antibody, and $\mathrm{Tg}$ antibody tests were negative in the serum. The CSF study showed mild pleocytosis and moderately elevated IL-6 (840 pg/mL). The EEG results were normal when the patient was in the interictal stage. On MRI examination 3 weeks after onset, the right optic nerve was swollen, short $\mathrm{T} 1$ inversion recovery hyperintense, and gadolinium-enhanced (figure 1, C and D). FLAIR hyperintensity in the right hemispheric cortex was seen, and the corresponding cortical layer was slightly swollen (figure 3, F-H) and partially gadolinium-enhanced. Meanwhile, hyperintensity was less evident in DWI and T2WI in the cortical region, but brain SPECT showed hyperperfusion in the region (figure 3I). Whole-body PET-CT showed no abnormal uptake suspicious of malignancy or inflammation. With a presumptive diagnosis of autoimmune encephalitis, HIMP was administered, and both neurologic and ocular symptoms fully resolved. Four weeks after admission, the patient was discharged without any symptoms. Oral PSL $(25 \mathrm{mg} / \mathrm{d}$, gradually tapered off in 2 years) and carbamazepine $(400 \mathrm{mg} / \mathrm{d})$ was continued, and he did not experience any relapse. At 40 months after discharge, the MOG antibody titer was reduced (1:128) and brain MRI showed no residual lesions (figure 3J).

Case 3. A 23-year-old man with involuntary movement of the left hand was diagnosed with epilepsy and was treated with carbamazepine $(400 \mathrm{mg} / \mathrm{d})$ with no apparent effect. One month later, he developed a generalized tonic seizure that lasted for 1 hour. The following month, he was admitted to our hospital for a severe headache. But he did not complain of visual impairment. Upon neurologic examination, he was disoriented without neck stiffness. Although the $\mathrm{CBC}$ and blood biochemistry results were normal, the MOG antibody test was positive in the serum $(1: 256)$ and in the CSF $(1: 16)$ (table 1). The GAD antibody, TPO antibody, and Tg antibody tests were negative in the serum. The EEG examination revealed rhythmic slow waves in the right hemisphere, especially in the right parietal region, but no epileptic discharge was seen in the interictal state. Brain MRI scanned 1 month after the onset of epilepsy showed FLAIR hyperintensity in the right hemispheric cortical region (figure 3, K-N). Abnormalities in the region in DWI, T2WI, and GdT1WI were equivocal. Whole-body CT showed no malignancy or inflammation. VEP was not examined. Tests for cytomegalovirus antigen in the blood and Mycobacterium tuberculosis (QuantiFERON) were negative, and PCR for herpes simplex virus (HSV), gram stains, and culture results were negative in the CSF. However, because we could not rule out CNS infectious disease, we initially treated the patient with IV ceftriaxone, isoniazid, ethambutol, acyclovir, fluconazole, and dexamethasone $(33 \mathrm{mg} / \mathrm{d})$. His symptoms disappeared soon after the treatment, and we suspected autoimmune encephalitis rather than CNS infection. Four weeks after admission, he was discharged with no symptoms, but oral prednisolone $(15 \mathrm{mg} / \mathrm{d}$, gradually tapered off in a year) and carbamazepine $(600 \mathrm{mg} / \mathrm{d})$ were continued. Eighteen months later, he had not experienced a relapse, and the MOG antibody was undetectable in the serum. No brain MRI lesions were seen 23 months after discharge (figure 3O).

Case 4. A 38-year-old man was admitted to a local hospital with headache and abnormal behavior (he was unable to dress himself). After admission, he experienced a generalized tonic seizure, and he was transferred to our hospital. Because the cause of the generalized tonic seizure was unknown despite 
Table 2 Differential diagnosis of autoimmune or immune-mediated encephalopathy

\begin{tabular}{|c|c|c|c|c|c|c|c|}
\hline & Age, y & Sex & Clinical manifestations & Autoantibodies & Brain MRI findings & Treatments & Prognosis \\
\hline Present cases & 23-39 & All male & $\begin{array}{l}\text { Seizure in all, abnormal } \\
\text { behavior, psychiatric } \\
\text { symptoms or other focal } \\
\text { brain symptoms in some } \\
\text { cases, no cancer }\end{array}$ & MOG antibody & $\begin{array}{l}\text { FLAIR-hyperintense } \\
\text { unilateral cerebral } \\
\text { cortical lesions, no } \\
\text { atrophy }\end{array}$ & HIMP, AED & $\begin{array}{l}\text { Full recovery, no } \\
\text { relapse }\end{array}$ \\
\hline ADEM $^{18}$ & $\begin{array}{l}\text { Children and } \\
\text { young adults } \\
(<40 \text { y) }\end{array}$ & Male $60 \%$ & $\begin{array}{l}\text { Altered consciousness } \\
\text { and behavior, weakness, } \\
\text { ataxia, cranial nerve } \\
\text { palsy, seizure, fever, } \\
\text { headache, vomiting, and } \\
\text { meningeal signs }\end{array}$ & $\begin{array}{l}\text { MOG antibody } \\
50 \%\end{array}$ & $\begin{array}{l}\text { T2/FLAIR multiple, } \\
\text { large lesions ( }>2 \mathrm{~cm} \text { ) in } \\
\text { the white matter, basal } \\
\text { ganglia, brainstem, } \\
\text { cerebellum, and spinal } \\
\text { cord }\end{array}$ & HIMP, IVIg, PLEX & $\begin{array}{l}\text { Full recovery in } \\
50 \%-89 \%\end{array}$ \\
\hline $\begin{array}{l}\text { Rasmussen } \\
\text { encephalitis }^{17}\end{array}$ & $\begin{array}{l}\text { Infancy to } \\
\text { adulthood (mean } \\
6 \text { y) }\end{array}$ & $\begin{array}{l}\text { No } \\
\text { predominance }\end{array}$ & $\begin{array}{l}\text { Hemiparesis, seizure, } \\
\text { and unilateral movement } \\
\text { disorder (athetosis/ } \\
\text { dystonia) }\end{array}$ & $\begin{array}{l}\text { GluR antibody in } \\
\text { some cases }\end{array}$ & $\begin{array}{l}\text { Unilateral hemispheric } \\
\text { focal cortical lesions } \\
\text { with atrophy }\end{array}$ & $\begin{array}{l}\text { AED, HIMP, IVIg, } \\
\text { PLEX, surgery }\end{array}$ & $\begin{array}{l}\text { Severe fixed } \\
\text { neurologic } \\
\text { deficit }\end{array}$ \\
\hline $\begin{array}{l}\text { NMDAR } \\
\text { encephalitis }^{18,19}\end{array}$ & $\begin{array}{l}8 \text { months- } 85 \\
\text { years (mean } \\
21 \text { y) }\end{array}$ & $\begin{array}{l}\text { Female } \\
\text { dominant }\end{array}$ & $\begin{array}{l}\text { Psychiatric disorder, } \\
\text { seizure, movement } \\
\text { disorder, autonomic } \\
\text { instability, and central } \\
\text { hypoventilation, ovarian } \\
\text { teratoma usually found } \\
\text { in young women }\end{array}$ & $\begin{array}{l}\text { NMDAR GluN1 } \\
\text { subunit antibody }\end{array}$ & $\begin{array}{l}\text { Abnormal, mainly } \\
\text { medial temporal lobe } \\
\text { lesions in half of cases }\end{array}$ & $\begin{array}{l}\text { HIMP, IVIg, PLEX, } \\
\text { rituximab }\end{array}$ & $\begin{array}{l}80 \% \text { recover or } \\
\text { have mild } \\
\text { deficits }\end{array}$ \\
\hline $\begin{array}{l}\text { VGKC-Ab-associated } \\
\text { encephalopathy }{ }^{18,20}\end{array}$ & $\begin{array}{l}\text { 47-77 years } \\
\text { (median 63) }\end{array}$ & Male dominant & $\begin{array}{l}\text { Amnesia, seizure, } \\
\text { psychiatric disturbance, } \\
\text { autonomic dysfunction, } \\
\text { and neuromyotonia }\end{array}$ & $\begin{array}{l}\text { LGI1, CASPR2 } \\
\text { antibodies }\end{array}$ & $\begin{array}{l}\text { T2/FLAIR } \\
\text { hyperintensity in the } \\
\text { medial temporal lobe, } \\
\text { hippocampus, or } \\
\text { amygdala in half of } \\
\text { cases }\end{array}$ & HIMP, PLEX, IVIg & $\begin{array}{l}\text { Often } \\
\text { monophasic }\end{array}$ \\
\hline $\begin{array}{l}\text { GAD-Ab-associated } \\
\text { limbic encephalitis }\end{array}$ & $\begin{array}{l}\text { 17-66 years } \\
\text { (median 23) }\end{array}$ & $\begin{array}{l}\text { Female } \\
\text { dominant }\end{array}$ & $\begin{array}{l}\text { Epilepsy, mild cognitive } \\
\text { disorder }\end{array}$ & $\begin{array}{l}\text { GAD antibody } \\
(>1,000 \mathrm{U} / \mathrm{mL})\end{array}$ & $\begin{array}{l}\text { High signal on T2 in } \\
\text { the medial temporal } \\
\text { lobe or hippocampus }\end{array}$ & HIMP, PLEX & $\begin{array}{l}\text { Chronic or } \\
\text { nonremitting } \\
\text { course }\end{array}$ \\
\hline $\begin{array}{l}\text { Other autoimmune } \\
\text { limbic encephalitis }\end{array}$ & $\begin{array}{l}\text { Hu antibody: } \\
50-63 \text { years; } \\
\text { Ma2 antibody: } \\
22-70 \text { years; } \\
\text { AMPA receptor } \\
\text { antibody: } 23-81 \\
\text { years; GABA } \\
\text { receptor antibody: } \\
16-77 \text { years }\end{array}$ & $\begin{array}{l}\text { Male dominant: } \\
\text { Hu, Ma2, } \\
\text { GABA }_{B} \\
\text { receptor } \\
\text { antibodies, } \\
\text { female } \\
\text { dominant: } \\
\text { AMPA receptor } \\
\text { antibody }\end{array}$ & $\begin{array}{l}\text { Confusion, working } \\
\text { memory deficit, mood } \\
\text { change, seizure } \\
\text { associated with tumors } \\
\text { (ex: small-cell lung } \\
\text { carcinoma, testicular } \\
\text { seminoma, thymoma) }\end{array}$ & $\begin{array}{l}\mathrm{Hu}, \mathrm{Ma2}, \mathrm{AMPA} \\
\text { receptor, GABA } \\
\text { receptor } \\
\text { antibodies }\end{array}$ & $\begin{array}{l}\text { FLAIR } \\
\text { hyperintensities in the } \\
\text { medial temporal lobe }\end{array}$ & $\begin{array}{l}\text { HIMP, IVIg, PLEX, } \\
\text { tumor treatment }\end{array}$ & $\begin{array}{l}\text { Differ according } \\
\text { to } \\
\text { autoantibodies } \\
\text { but rarely fully } \\
\text { recover }\end{array}$ \\
\hline $\begin{array}{l}\text { Hashimoto } \\
\text { encephalopathy }\end{array}$ & $\begin{array}{l}23-83 \text { years } \\
\text { (mean } 60 \text { years) }\end{array}$ & $\begin{array}{l}\text { Female } \\
\text { dominant }\end{array}$ & $\begin{array}{l}\text { Seizure, myoclonus, } \\
\text { hallucination, or stroke- } \\
\text { episodes }\end{array}$ & $\begin{array}{l}\text { Thyroid } \\
\text { peroxidase, } \\
\text { thyroglobulin } \\
\text { antibodies, } \\
\alpha \text {-enolase } \\
\text { antibody }\end{array}$ & $\begin{array}{l}\text { Normal or nonspecific } \\
\text { abnormalities }\end{array}$ & HIMP & $\begin{array}{l}\text { Improvement in } \\
\text { most patients }\end{array}$ \\
\hline NMOSD $^{10,24,25}$ & $\begin{array}{l}\text { AQP4 antibody- } \\
\text { positive: around } \\
40 \text { years on } \\
\text { average, } 1 \%-2 \% \\
\text { in children, MOG } \\
\text { antibody-positive: } \\
3-70 \text { years } \\
\text { (median: } 37.5 \\
\text { years) }\end{array}$ & $\begin{array}{l}\text { AQP4 } \\
\text { antibody- } \\
\text { positive: } \\
\text { female domi- } \\
\text { nant }(60 \%- \\
90 \%), \text { MOG } \\
\text { antibody- } \\
\text { positive: no } \\
\text { female } \\
\text { preponderance }\end{array}$ & $\begin{array}{l}\text { Optic neuritis, acute } \\
\text { myelitis, hiccups or } \\
\text { nausea and vomiting, } \\
\text { acute brainstem } \\
\text { syndrome, symptomatic } \\
\text { narcolepsy or acute } \\
\text { diencephalic clinical } \\
\text { syndrome, symptomatic } \\
\text { cerebral syndrome }\end{array}$ & $\begin{array}{l}\text { AQP4 antibody, } \\
\text { MOG antibody }\end{array}$ & $\begin{array}{l}\text { AQP4 antibody- } \\
\text { positive: dorsal medulla/ } \\
\text { area postrema, peri- } \\
\text { ependymal brainstem, } \\
\text { subcortical or deep } \\
\text { white matter, corpus } \\
\text { callosum, long cortico- } \\
\text { spinal tract lesions, } \\
\text { MOG antibody positive: } \\
\text { ADEM, brainstem } \\
\text { lesions }\end{array}$ & $\begin{array}{l}\text { HIMP, PLEX, IVIg, } \\
\text { cyclophosphamide in } \\
\text { acute attacks, } \\
\text { immunosuppressants } \\
\text { for relapse prevention }\end{array}$ & $\begin{array}{l}\text { AQP4-positive: } \\
\text { more than one- } \\
\text { third could not } \\
\text { walk without } \\
\text { unilateral } \\
\text { assistance, } \\
\text { MOG antibody- } \\
\text { positive: rela- } \\
\text { tively benign }\end{array}$ \\
\hline
\end{tabular}

Abbreviations: ADEM = acute disseminated encephalomyelitis; AED = antiepileptic drug; AQP4 = aquaporin-4; DWI = diffusion-weighed imaging; FLAIR = fluid-attenuated inversion recovery; GAD = glutamic acid decarboxylase; HIMP = high-dose IV methylprednisolone; IVIg = IV immunoglobulin; MOG = myelin oligodendrocyte glycoprotein; NMDAR = NMDA receptor; NMOSD = neuromyelitis optica spectrum disorders; PLEX = plasma exchange; VGKC $=$ voltage-gated potassium channel.

a diagnostic workup, he was discharged 1 week later (carbamazepine was continued). However, 35 months after the first admission, he developed a generalized tonic seizure, which initially involved the right hand. He also had aphasia and right hemiparesis and was readmitted to our hospital. Neurologic examination revealed delirium, emotional incontinence, aphasia, and mild right hemiparesis. He did not show ocular symptoms during the course of disease. The
$\mathrm{CBC}$ and blood biochemistry were normal, but the MOG antibody test was positive in the serum $(1: 1,024)$ (table 1$)$. Serum GAD antibody, TPO antibody, and $\mathrm{Tg}$ antibody tests were negative. Brain MRI scanned 4 days after the second episode of epilepsy showed FLAIR hyperintensity in the left hemispheric cortical region (figure 3, P-R). Brain SPECT demonstrated hyperperfusion in the region (figure $3 S$ ). Whole-body PET-CT findings showed no malignancy 
or swollen lymph nodes. VEP was not done. PCR for $\mathrm{HSV}$, gram stains, and culture results were negative in the CSF. After admission, his symptoms became worse (agitation and violent behavior) despite the administration of sedatives. We suspected autoimmune encephalitis and started HIMP, after which time he became asymptomatic and was discharged. He continued carbamazepine $(300 \mathrm{mg} / \mathrm{d})$ and experienced no relapse. At 84 months after discharge, he was MOG antibodynegative. A brain MRI taken 72 months after discharge was normal (figure 3T).

DISCUSSION In the index case (case 1), we tested for MOG antibody because the patient had unilateral benign $\mathrm{ON}$ rather than unilateral cortical encephalitis with epileptic seizure. Then, we tested for MOG antibody in our cohort of 24 consecutive adult cases of corticosteroid-responsive encephalitis of unknown etiology and identified 3 additional patients with MOG antibody positivity. Unexpectedly, these 3 MOG antibody-positive patients also had unilateral cortical encephalitis with epileptic seizure as seen in the index case, and there were no cases of unilateral cortical encephalitis with epileptic seizure without MOG antibody positivity in our cohort. The unilateral cortical lesions best depicted by FLAIR images were unique and appeared distinct from brain lesions previously described in MOG antibody-positive diseases including ADEM. ${ }^{13}$

The unilateral cortical lesions in our cases $1-4$ needed to be differentiated from seizure-induced brain MRI abnormalities. ${ }^{14}$ Such brain MRI abnormalities induced by epileptic seizure are localized in the corti$\mathrm{cal} /$ subcortical regions, hippocampus, basal ganglia, white matter, or corpus callosum, and they are readily visible on DWI due to cytotoxic changes. ${ }^{15,16}$ However, the MRI findings in our cases were much more clearly seen in FLAIR images than in DWI and ADC findings (figure 1, A-F). Moreover, pleocytosis in the CSF and a favorable response to HIMP suggested that the unique unilateral cortical lesions were inflammatory, and hyperperfusion on SPECT corresponding to the cortical FLAIR hyperintensity supported the inflammatory nature and epileptogenicity of the swollen cortical lesions in the acute phase.

We also ruled out a variety of autoantibodymediated or immune-mediated encephalitides (table 2) before we concluded that the unilateral cortical encephalitis with epileptic seizure in our cases was unique. Rasmussen encephalitis (RE) is described as unilateral cerebral cortical encephalitis, similar to that observed in our patients. However, RE is clinically characterized by focal epilepsy, progressive hemiplegia, and cognitive decline with unilateral hemispheric focal cortical atrophy in the chronic stage, and corticosteroid and other anti-inflammatory therapies are only partially effective. ${ }^{17}$ Our cases did not share these features of RE or fulfill the diagnostic criteria. The lesion distribution in our 4 patients was also dissimilar to the brain MRI abnormalities in cases of encephalitis with seizure associated with NMDAR antibody, VGKC antibody, GAD antibody, and antithyroid antibodies, ${ }^{18-22}$ and our patients were negative for those autoantibodies. Likewise, the clinical and neuroimaging features of our cases were distinct from limbic encephalitides with positivity for GAD, LGI1, $\mathrm{GABA}_{\mathrm{B}}$, or AMPA antibodies ${ }^{18}$ and from the brain syndrome previously described in NMOSD. ${ }^{10,23,24}$

FLAIR-hyperintense lesions localized at the cerebral cortex or sulcus, similar to the findings observed in the present cases, can develop in various CNS diseases including meningitis, subarachnoid hemorrhage, leptomeningeal metastasis, acute infarction, and moyamoya disease. ${ }^{25}$ In a review of such MRI abnormalities, the left temporo-occipital cortical FLAIR-hyperintense lesions in a 23-year-old man with the diagnosis of meningitis appeared to be similar to the brain MRI findings in our cases. More recently, Numa et al. ${ }^{26}$ reported a case of a 37-year-old woman who was diagnosed with ADEM when she was 4 years old and developed $O N$ followed by recurrent ADEM 33 years later. She was MOG antibody-positive, and brain MRI showed unique cortical FLAIR-hyperintense lesions in the left temporal and frontal lobes. Thus, unilateral cortical encephalitis in MOG antibody-positive patients, as in the 4 cases in our study, may have been previously unnoted as a distinct phenotype. The relationship between MOG antibody and the unilateral cerebral cortical encephalitis observed in our cases remains unclear. Two of our patients had benign unilateral $\mathrm{ON}$, in which MOG antibody is often detected, while cases 3 and 4 lacked such characteristics of CNS diseases such as ON, LETM, NMOSD, or ADEM. ${ }^{2,3,7-}$ 10,12,13,27-29 Thus, unilateral cerebral cortical encephalitis may be another characteristic manifestation of MOG antibody-positive patients. Although some cases of MOG antibody-associated diseases fulfill the diagnostic criteria of seronegative NMOSD, ${ }^{23}$ the spectrum of MOG antibody-associated diseases is obviously wider than NMOSD. In the near future, MOG antibodyassociated diseases may be recognized as a distinct clinical entity of inflammatory demyelinating diseases of the CNS. ${ }^{30}$

There is some evidence to support the pathogenic potential of MOG antibody. Experimental studies have shown that MOG antibody can affect oligodendrocytes and myelins. ${ }^{31,32}$ In addition, in a few brainbiopsied cases of tumefactive brain lesions with MOG antibody positivity, pathologic examinations revealed active inflammatory demyelination with deposition of immunoglobulins and complement ${ }^{33,34}$ or MS type II pathology. ${ }^{35,36}$ Moreover, we recently reported high 
CSF-MBP levels without elevated CSF glial fibrillary acidic protein levels, an astrocytic damage marker, in MOG antibody-positive patients. ${ }^{37}$ These findings suggest that MOG antibody may directly contribute to inflammatory demyelination in anti-myelin antibody-associated CNS diseases. However, in 3 of our MOG antibody-positive cases whose CSF-MBP levels were measured during the acute phase, there was no elevation in CSF-MBP despite the extensive cortical involvement and CSF pleocytosis. Thus, it is also possible that MOG antibody itself may not be directly associated with the unilateral cerebral cortical encephalitis with epileptic seizure in our patients and that another autoimmune disorder coexisting with MOG antibody positivity might be responsible for the encephalitis. In fact, MOG antibody can be detected in some patients with other autoantibodyassociated encephalitides such as NMDAR antibodypositive encephalitis. ${ }^{38}$ In addition, a pathogenic autoantibody may be generated years before the clinical onset of disease, as seen in AQP4 antibody-positive NMOSD. ${ }^{39}$ Accordingly, CNS lesions associated with MOG antibody may possibly develop later in the disease course of cases 3 and 4 . Therefore, an unknown autoantibody might be associated with the unilateral cerebral cortical encephalitis with epileptic seizure in a fraction of MOG antibody-positive cases although we need to perform immunohistochemistry or immunofluorescence with rodent brain tissue slices and the sera and CSF from the patients as an attempt to see whether there are any antibody reactivities to the cerebral cortical tissues.

Our study is retrospective and has some limitations. Because our patient cohort was small and derived from a single university hospital, the results should be verified in prospective, larger-scale, multicenter studies. In addition, we analyzed only adult patients in the present study, and it is important to determine whether MOG antibody-positive unilateral cerebral cortical encephalitis with epileptic seizure also occurs in children. Therefore, at this point, it is premature to discuss the frequency of MOG antibody-positive unilateral cerebral cortical encephalitis in corticosteroid-responsive encephalitis of unknown etiology. However, since we experienced 6 cases of NMDAR antibody-associated encephalitis and 1 with VGKC antibody-associated encephalitis during the same period (2008-2014), unilateral encephalitis with MOG antibody may not be so uncommon.

Taken together, we report a form of benign unilateral cerebral cortical encephalitis with epileptic seizure in 4 adult patients with MOG antibody positivity. The pathogenesis of this condition appears to be immune-mediated or autoantibody-mediated, although the clinical, MRI, and laboratory features differ from those in previously described MOG antibody-associated CNS diseases (3, $^{3,10,13,40}$ and known autoantibody-mediated encephalitides. ${ }^{18}$ Another autoantibody that coexists with MOG antibody may be responsible for this type of encephalitis.

\section{AUTHOR CONTRIBUTIONS}

R.O. analyzed the data and wrote the paper, substantial contribution to the study conception, acquisition, analysis, and interpretation of data for the work, writing the manuscript, drafting and correction of all versions of the manuscript including figures, tables, and references, completion of the work to be submitted, provided final approval of the version to be published, agreed to be accountable for all aspects of the work. I.N. substantial contribution to the conception and design of the work, as well as supervision of the acquisition, analysis, and interpretation of data for the work, revised several versions of the manuscript critically for important intellectual content, provided final approval of the version to be published, agreed to be accountable for all aspects of the work. T.T. substantial contribution to the conception and design of the work, as well as supervision of the acquisition, analysis, and interpretation of data for the work, revised several versions of the manuscript critically for important intellectual content, provided final approval of the version to be published, agreed to be accountable for all aspects of the work. K.K. contribution to the plan of the work, acquisition, analysis, interpretation of data for the work, and drafting the original manuscript related to the case, provided final approval of the version to be published, agreed to be accountable for all aspects of the work. T.A. acquisition, analysis, and interpretation of data for the work, provided final approval of the version to be published, agreed to be accountable for all aspects of the work. Y.T. acquisition, analysis, and interpretation of data for the work, provided final approval of the version to be published, agreed to be accountable for all aspects of the work. D.K.S. acquisition, analysis, and interpretation of data for the work, provided final approval of the version to be published, agreed to be accountable for all aspects of the work. S.N. acquisition, analysis, and interpretation of data for the work, provided final approval of the version to be published, agreed to be accountable for all aspects of the work. T.M. acquisition, analysis, and interpretation of data for the work, provided final approval of the version to be published, agreed to be accountable for all aspects of the work. H.K. substantial contribution to the conception and design of the work, as well as supervision of the acquisition, analysis, and interpretation of data for the work, revised several versions of manuscript critically for important intellectual content, provided final approval of the version to be published, agreed to be accountable for all aspects of the work. M.A. substantial contribution to the conception and design of the work, as well as supervision of the acquisition, analysis, and interpretation of data for the work, provided final approval of the version to be published, agreed to be accountable for all aspects of the work. K.F. substantial contribution to the conception and design of the work, as well as supervision of the acquisition, analysis, and interpretation of data for the work, supervision of the manuscript preparation, revised several versions of the manuscript critically for important intellectual content, final responsibility and approval of the version to be published, agreed to be accountable for all aspects of the work.

\section{ACKNOWLEDGMENT}

The authors thank Yuri Atobe and Kaori Tobise for technical assistance.

\section{STUDY FUNDING}

This study was partially supported by a grant-in-aid for scientific research from the Japan Society for the Promotion of Science (KAKENHI), the Health and Labour Sciences Research Grant on Intractable Diseases (neuroimmunologic diseases) from the Ministry of Health, Labour and Welfare of Japan.

\section{DISCLOSURES}

R. Ogawa reports no disclosures. I. Nakashima received travel funding and speaker honoraria from Biogen Japan, Tanabe Mitsubishi, and Novartis Pharma; is on the editorial board for Multiple Sclerosis International; and received research support from LSI Medience Corporation. T. Takahashi received speaker honoraria from Biogen Idec and Cosmic 
Corporation and received research support from Cosmic Corporation. $\mathrm{K}$. Kaneko and T. Akaishi report no disclosures. Y. Takai received research support from Ministry of Education, Culture, Sports, Science and Technology of Japan. D.K. Sato served on the advisory board for Merck, Teva, and Shire; received speaker honoraria from Novartis, Genzyme, Merck-Serono, Biogen, Teva, Bayer, and Roche; is an associate editor for Arquivos de Neuropsiquiatria; and received research support from Ministry of Education, Culture, Sports, Science and Technology in Japan, Japan Society for the Promotion of Science, and CAPES/Brasil. S. Nishiyama received research support from Japan Society for the Promotion of Science. T. Misu received speaker honoraria from Bayer Schering Pharma and Biogen Idec Japan; and received research support from Ministry of Education, Culture, Sports, Science and Technology, Ministry of Health, Labor and Welfare of Japan. H. Kuroda received research support from Ministry of Education, Culture, Sports, Science and Technology of Japan. M. Aoki received research support from Japanese Ministry of Health Labor and Welfare, Japanese Ministry of Education, Culture, Sports, Science and Technology. K. Fujihara serves on the advisory boards for Bayer Schering Pharma, Biogen Idec, Mitsubishi Tanabe Pharma Corporation, Novartis Pharma, Chugai Pharmaceutical, Ono Pharmaceutical, Nihon Pharmaceutical, Alexion Pharmaceuticals, and Medimmune; has received travel funding and speaker honoraria from Bayer Schering Pharma, Biogen Idec, Eisai Inc, Mitsubishi Tanabe Pharma Corporation, Novartis Pharma, Astellas Pharma Inc., Takeda Pharmaceutical Company Limited, Asahi Kasei Medical Co., Daiichi Sankyo, and Nihon Pharmaceutical; is on the editorial board for Clinical and Experimental Neuroimmunology; is an advisory board member for Sri Lanka Journal of Neurology; and received research support from Bayer Schering Pharma, Biogen Idec Japan, Asahi Kasei Medical, The Chemo-Sero-Therapeutic Research Institute, Teva Pharmaceutical, Mitsubishi Tanabe Pharma, Teijin Pharma, Chugai Pharmaceutical, Ono Pharmaceutical, Nihon Pharmaceutical, Genzyme Japan, Ministry of Education, Science and Technology of Japan, and Ministry of Health, Welfare and Labor of Japan. Go to Neurology.org/nn for full disclosure forms.

Received December 5, 2016. Accepted in final form December 15, 2016.

\section{REFERENCES}

1. Johns TG, Bernard CC. The structure and function of myelin oligodendrocyte glycoprotein. J Neurochem 1999;72:1-9.

2. Reindl M, Di Pauli F, Rostasy K, Berger T. The spectrum of MOG autoantibody-associated demyelinating diseases. Nat Rev Neurol 2013;9:455-461.

3. Ramanathan S, Dale RC, Brilot F. Anti-MOG antibody: the history, clinical phenotype, and pathogenicity of a serum biomarker for demyelination. Autoimmun Rev 2016;15:307-324.

4. Merkler D, Schmelting B, Czeh B, Fuchs E, Stadelmann C, Bruck W. Myelin oligodendrocyte glycoprotein-induced experimental autoimmune encephalomyelitis in the common marmoset reflects the immunopathology of pattern II multiple sclerosis lesions. Mult Scler 2006; 12:369-374.

5. Stassart RM, Helms G, Garea-Rodriguez E, et al. A new targeted model of experimental autoimmune encephalomyelitis in the common marmoset. Brain Pathol 2016; 26:452-464.

6. Zhou D, Srivastava R, Nessler S, et al. Identification of a pathogenic antibody response to native myelin oligodendrocyte glycoprotein in multiple sclerosis. Proc Natl Acad Sci USA 2006;103:19057-19062.

7. Lalive $\mathrm{PH}$, Hausler MG, Maurey $\mathrm{H}$, et al. Highly reactive anti-myelin oligodendrocyte glycoprotein antibodies differentiate demyelinating diseases from viral encephalitis in children. Mult Scler 2011;17:297-302.
8. Waters P, Woodhall M, O'Connor KC, et al. MOG cellbased assay detects non-MS patients with inflammatory neurologic disease. Neurol Neuroimmunol Neuroinflamm 2015;2:e89. doi: 10.1212/NXI.0000000000000089.

9. Kitley J, Waters P, Woodhall M, et al. Neuromyelitis optica spectrum disorders with aquaporin- 4 and myelinoligodendrocyte glycoprotein antibodies: a comparative study. JAMA Neurol 2014;71:276-283.

10. Sato DK, Callegaro D, Lana-Peixoto MA, et al. Distinction between MOG antibody-positive and AQP4 antibody-positive NMO spectrum disorders. Neurology 2014;82:474-481.

11. Rostasy K, Mader S, Hennes EM, et al. Persisting myelin oligodendrocyte glycoprotein antibodies in aquaporin- 4 antibody negative pediatric neuromyelitis optica. Mult Scler 2013;19:1052-1059.

12. Jarius S, Ruprecht $\mathrm{K}$, Kleiter I, et al. MOG-IgG in NMO and related disorders: a multicenter study of 50 patients: part 2: epidemiology, clinical presentation, radiological and laboratory features, treatment responses, and long-term outcome. J Neuroinflammation 2016;13:280.

13. Kim SM, Woodhall MR, Kim JS, et al. Antibodies to MOG in adults with inflammatory demyelinating disease of the CNS. Neurol Neuroimmunol Neuroinflamm 2015; 2:e163. doi: 10.1212/NXI.0000000000000163.

14. Cianfoni A, Caulo M, Cerase A, et al. Seizure-induced brain lesions: a wide spectrum of variably reversible MRI abnormalities. Eur J Radiol 2013;82:1964-1972.

15. Chatzikonstantinou A, Gass A, Forster A, Hennerici MG, Szabo K. Features of acute DWI abnormalities related to status epilepticus. Epilepsy Res 2011;97:45-51.

16. Milligan TA, Zamani A, Bromfield E. Frequency and patterns of MRI abnormalities due to status epilepticus. Seizure 2009;18:104-108.

17. Varadkar S, Bien CG, Kruse CA, et al. Rasmussen's encephalitis: clinical features, pathobiology, and treatment advances. Lancet Neurol 2014;13:195-205.

18. Graus F, Titulaer MJ, Balu R, et al. A clinical approach to diagnosis of autoimmune encephalitis. Lancet Neurol 2016;15:391-404.

19. Titulaer MJ, McCracken L, Gabilondo I, et al. Treatment and prognostic factors for long-term outcome in patients with anti-NMDA receptor encephalitis: an observational cohort study. Lancet Neurol 2013;12:157-165.

20. Huda S, Wong SH, Pettingill P, O'Connell D, Vincent A, Steiger M. An 11-year retrospective experience of antibodies against the voltage-gated potassium channel (VGKC) complex from a tertiary neurological centre. J Neurol 2015;262:418-424.

21. Malter MP, Helmstaedter C, Urbach H, Vincent A, Bien CG. Antibodies to glutamic acid decarboxylase define a form of limbic encephalitis. Ann Neurol 2010;67:470-478.

22. Yoneda M, Fujii A, Ito A, Yokoyama H, Nakagawa H, Kuriyama M. High prevalence of serum autoantibodies against the amino terminal of alpha-enolase in Hashimoto's encephalopathy. J Neuroimmunol 2007;185: 195-200.

23. Wingerchuk DM, Banwell B, Bennett JL, et al. International consensus diagnostic criteria for neuromyelitis optica spectrum disorders. Neurology 2015;85:177-189.

24. Zekeridou A, Lennon VA. Aquaporin-4 autoimmunity. Neurol Neuroimmunol Neuroinflamm 2015;2:e110. doi: 10.1212/NXI.0000000000000110. 
25. Maeda M, Yagishita A, Yamamoto T, Sakuma H, Takeda K. Abnormal hyperintensity within the subarachnoid space evaluated by fluid-attenuated inversion-recovery MR imaging: a spectrum of central nervous system diseases. Eur Radiol 2003;13(suppl 4):L192-L201.

26. Numa S, Kasai T, Kondo T, et al. An adult case of anti-myelin oligodendrocyte glycoprotein (MOG) antibody-associated multiphasic acute disseminated encephalomyelitis at 33-year intervals. Intern Med 2016;55:699-702.

27. O'Connor KC, McLaughlin KA, De Jager PL, et al. Selfantigen tetramers discriminate between myelin autoantibodies to native or denatured protein. Nat Med 2007;13:211-217.

28. Brilot F, Dale RC, Selter RC, et al. Antibodies to native myelin oligodendrocyte glycoprotein in children with inflammatory demyelinating central nervous system disease. Ann Neurol 2009;66:833-842.

29. Huppke P, Rostasy K, Karenfort M, et al. Acute disseminated encephalomyelitis followed by recurrent or monophasic optic neuritis in pediatric patients. Mult Scler 2013;19:941-946.

30. Zamvil SS, Slavin AJ. Does MOG Ig-positive AQP4seronegative opticospinal inflammatory disease justify a diagnosis of NMO spectrum disorder? Neurol Neuroimmunol Neuroinflamm 2015;2:e62. doi: 10. 1212/NXI.0000000000000062.

31. Dale RC, Tantsis EM, Merheb V, et al. Antibodies to MOG have a demyelination phenotype and affect oligodendrocyte cytoskeleton. Neurol Neuroimmunol Neuroinflamm 2014;1: e12. doi: 10.1212/NXI.0000000000000012.

32. Saadoun S, Waters P, Owens GP, Bennett JL, Vincent A, Papadopoulos MC. Neuromyelitis optica MOG-IgG causes reversible lesions in mouse brain. Acta Neuropathol Commun 2014;2:35.

33. Konig FB, Wildemann B, Nessler S, et al. Persistence of immunopathological and radiological traits in multiple sclerosis. Arch Neurol 2008;65:1527-1532.

34. Spadaro M, Gerdes LA, Mayer MC, et al. Histopathology and clinical course of MOG-antibody-associated encephalomyelitis. Ann Clin Transl Neurol 2015;2:295-301.

35. Lucchinetti C, Bruck W, Parisi J, Scheithauer B, Rodriguez M, Lassmann $\mathrm{H}$. Heterogeneity of multiple sclerosis lesions: implications for the pathogenesis of demyelination. Ann Neurol 2000;47:707-717.

36. Spadaro M, Gerdes LA, Krumbholz M, et al. Autoantibodies to MOG in a distinct subgroup of adult multiple sclerosis. Neurol Neuroimmunol Neuroinflamm 2016;3: e257. doi: 10.1212/NXI.0000000000000257.

37. Kaneko K, Sato DK, Nakashima I, et al. Myelin injury without astrocytopathy in neuroinflammatory disorders with MOG antibodies. J Neurol Neurosurg Psychiatry 2016;87:1257-1259.

38. Titulaer MJ, Hoftberger R, lizuka T, et al. Overlapping demyelinating syndromes and anti-N-methyl-D-aspartate receptor encephalitis. Ann Neurol 2014;75:411-428.

39. Nishiyama $\mathrm{S}$, Ito $\mathrm{T}, \mathrm{Misu} \mathrm{T}$, et al. A case of NMO seropositive for aquaporin- 4 antibody more than 10 years before onset. Neurology 2009;72:1960-1961.

40. Baumann M, Sahin K, Lechner C, et al. Clinical and neuroradiological differences of paediatric acute disseminating encephalomyelitis with and without antibodies to the myelin oligodendrocyte glycoprotein. J Neurol Neurosurg Psychiatry 2015;86:265-272. 


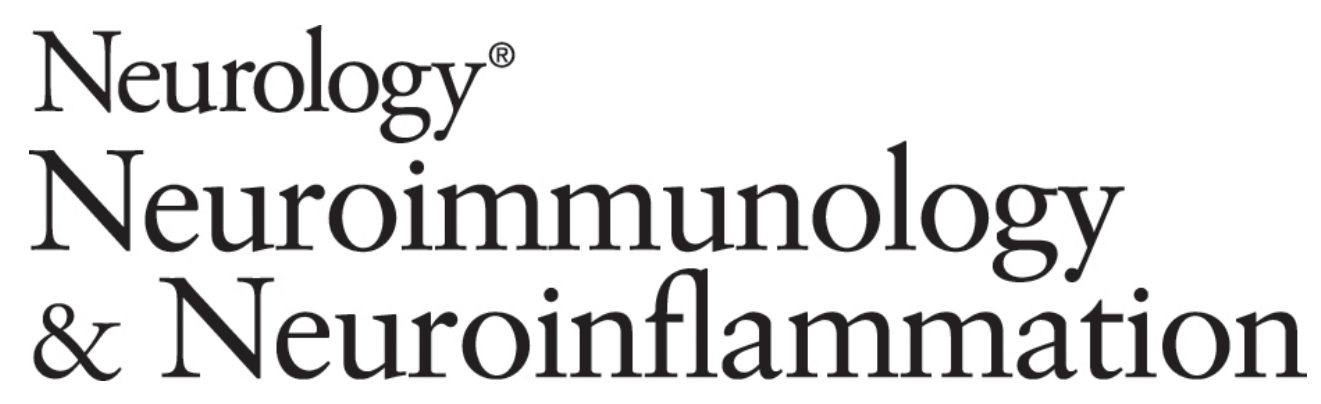

MOG antibody-positive, benign, unilateral, cerebral cortical encephalitis with epilepsy Ryo Ogawa, Ichiro Nakashima, Toshiyuki Takahashi, et al.

Neurol Neuroimmunol Neuroinflamm 2017;4;

DOI 10.1212/NXI.0000000000000322

This information is current as of January 16, 2017

Neurol Neuroimmunol Neuroinflamm is an official journal of the American Academy of Neurology.

Published since April 2014, it is an open-access, online-only, continuous publication journal. Copyright

Copyright $\odot 2017$ The Author(s). Published by Wolters Kluwer Health, Inc. on behalf of the American

Academy of Neurology. All rights reserved. Online ISSN: 2332-7812.

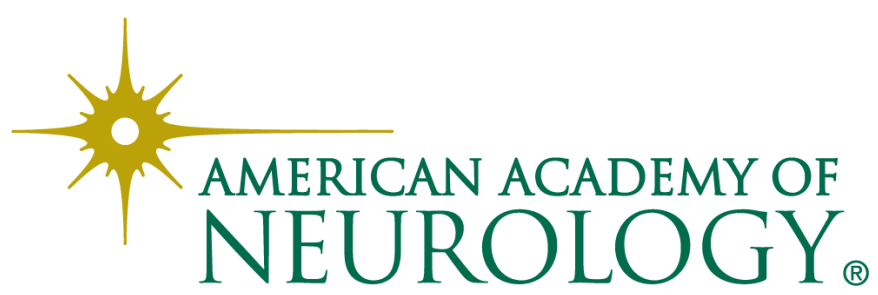




\section{Updated Information \& Services}

References

Citations

Subspecialty Collections

Permissions \& Licensing

Reprints including high resolution figures, can be found at: http://nn.neurology.org/content/4/2/e322.full.html

This article cites 40 articles, 3 of which you can access for free at: http://nn.neurology.org/content/4/2/e322.full.html\#\#ref-list-1

This article has been cited by 14 HighWire-hosted articles: http://nn.neurology.org/content/4/2/e322.full.html\#\#otherarticles

This article, along with others on similar topics, appears in the following collection(s):

All Demyelinating disease (CNS)

http://nn.neurology.org//cgi/collection/all_demyelinating_disease_cns All Epilepsy/Seizures

http://nn.neurology.org//cgi/collection/all_epilepsy_seizures

Autoimmune diseases

http://nn.neurology.org//cgi/collection/autoimmune_diseases

MRI

http://nn.neurology.org//cgi/collection/mri

Information about reproducing this article in parts (figures,tables) or in its entirety can be found online at:

http://nn.neurology.org/misc/about.xhtml\#permissions

Information about ordering reprints can be found online:

http://nn.neurology.org/misc/addir.xhtml\#reprintsus

Neurol Neuroimmunol Neuroinflamm is an official journal of the American Academy of Neurology.

Published since April 2014, it is an open-access, online-only, continuous publication journal. Copyright

Copyright $\odot 2017$ The Author(s). Published by Wolters Kluwer Health, Inc. on behalf of the American Academy of Neurology. All rights reserved. Online ISSN: 2332-7812.

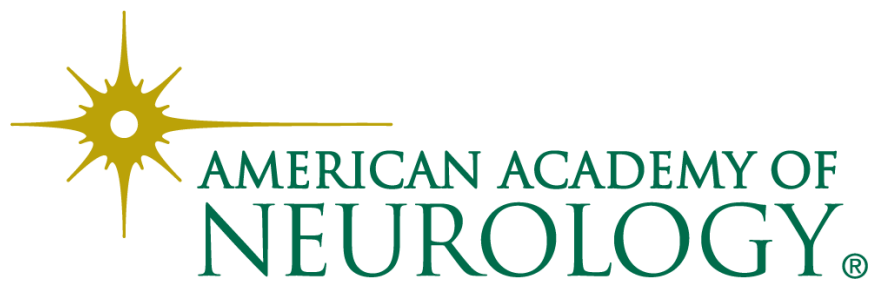

